\title{
HERNÁN NÚÑEZ DE TOLEDO, Glosa sobre las «Trezientas» del famoso poeta Juan de Mena, edición crítica y estudio de Julian Weiss y Antonio Cortijo Ocaña, Madrid, Ediciones Polifemo, 2015, 1258 pp.
}

\section{José María Balcells Doménech Universidad de León}

En 1977 publicó María Dolores de Asís una monografía rara de encontrar porque, al habérsela editado la propia autora, la distribución del libro fue reducidísima. Tenía como título Hernán Núñez en la historia de los estudios clásicos. Con esa obra se ponía la primera piedra en la atención crítica contemporánea a uno de los más importantes humanistas españoles.

Pero iba a tardar no pocas décadas la recuperación histórica y filológica de la figura y de la obra de quien, además de ser nombrado como El Comendador Griego, por serlo de la Orden de Santiago desde los catorce años, y por ser un gran helenista, también fue conocido como Hernán Núñez de Toledo, Hernán Núñez de Guzmán, e incluso como El Pinciano, al haber nacido en Valladolid, ciudad donde nació el que ostentaría ese gentilicio por antonomasia, El Pinciano Alonso López.

Cabe afirmar que, salvo excepciones, y uno de los editores del libro que reseñamos es una excepción, Julian Weiss, porque lleva casi un cuarto de siglo dedi- cado al estudio de Hernán Núñez, la bibliografía sobre el autor ha comenzado a incrementarse en el tercer milenio, marcando un antes y un después el volumen que acerca de la biblioteca y epistolario del vallisoletano se publicó en el año 2001, y que tiene la triple autoría de Juan Signes Codoñer, Carmen Codoñer Merino y Arantxa Domingo Malvadi. Y justo en ese año saldría aún otra obra que iba a remarcar esa dirección recuperadora del humanista, al ser publicada en dos volúmenes la edición crítica de sus Refranes o proverbios en romance (1555), labor que llevaron a cabo L. Combet, J. Sevilla, G. Conde y J. Guía.

Desde entonces se han ido aportando estudios al respecto, aportes que han firmado Frank A. Domínguez, Margarita Freixas Alós, Isidoro Arén Janeiro, Julian Weiss y Antonio Cortijo Ocaña, autores los dos últimos de la edición crítica de la Glosa sobre las «Trezientas» del famoso poeta Juan de Mena. Gracias sobre todo a este trabajo editor, de erudición y de estudio críticos, puede afirmarse ya que Hernán Núñez está comenzando a alcanzar el 
reconocimiento crítico al que tenía sobrado derecho su espléndida trayectoria humanística y su esfuerzo filológico para esclarecer y divulgar la más importante creación del poeta de Córdoba. Esos dos fines los señalaba él mismo diciendo, a propósito de sus comentarios al Laberinto, que eran un «amphiteatro abierto $y$ claro donde todos assi doctos como indoctos puedan sin miedo alguno entrar» (1051).

Julian Weiss enseña e investiga en el King's College de Londres, y Antonio Cortijo Ocaña lo viene haciendo desde hace muchos años en la Universidad de California en Santa Bárbara. Muy avezados investigadores ambos filólogos en las letras medievales y del Renacimiento, a las que han ido contribuyendo con diversos y valiosos aportes, las diversas vicisitudes, el esfuerzo y saberes comunes que se conjugan en el resultado de esta edición la convierten en obra de referencia en el campo del Humanismo hispánico y románico.

Un anticipo de este trabajo ya fue adelantado en la revista digital ehumanista, editada por la Universidad de California en Santa Bárbara, y de la que Antonio Cortijo Ocaña fue fundador en 1999. Esa amplia muestra se ofrece completada en este libro cuya publicación ha corrido a cargo del sello madrileño Ediciones Polifemo en 2015, un buen año para Juan de Mena, porque también tiene esa misma datación el grupo de estudios reunidos en el volumen Juan de Mena, de letrado a poeta, que coordinó para Támesis Cristina Moya García. Esta investigadora ha coordinado también otra reunión de trabajos sobre Mena (Ediciones Sílex, 2016) bajo el título de Juan de Mena: tiempo y memoria.

En esta obra hermenéutica de Hernán Núñez sobre la creación cumbre de Juan de Mena se involucraban muchos prestigios que se potenciaron entre sí. Ya en el propio título de la glosa del Laberinto de Fortuna, o Trescientas, se menciona expresamente al «famoso poeta» que fue el autor cordobés. Y esa fama contribuiría mucho a acrecentarla el Comendador griego, aumentando su nombradía filológica, merced a las repetidas ediciones de su Glosa que se fueron sucediendo desde 1499 hasta casi avistar el último tercio del siglo XVI.

Cuando Hernán Núñez obtiene en 1924 la cátedra de griego en la Universidad de Salamanca, después de haberla ostentado en la de Alcalá, llega a la ciudad del Tormes con un currículo en el cual constan hasta ocho ediciones de su comentario a dicho texto mayor de Juan de Mena. Y en esa ciudad, donde desempeñará también la cátedra de Retórica desde 1527, habrá de conocer otras seis más antes de su fallecimiento el 2 de septiembre de 1553. El año anterior a su muerte se había reeditado su trabajo en Amberes, y en 1566, ya con carácter póstumo, en Alcalá de Henares.

Esas cifras resultan bien espectaculares, y debieron contribuir no poco a consolidar su autoridad como filólogo y como humanista en el Estudio salmanticense, en el que le ocuparon otros trabajos muy notables, así sus comentarios

LECTURA Y SIGNO, 11 (2016), pp. 111-113 
a la Historia Natural de Plinio, la edición de las obras de Séneca, con extraordinaria repercusión editorial también, apareciendo póstumamente en esa ciudad el fruto de una de sus más ingentes tareas, Romances y proverbios en romance.

Francisco Sánchez de las Brozas, llamado El Brocense, catedrático de griego igualmente en Salamanca, trabajó en la edición del Laberinto de Fortuna con menos repercusión editorial, aunque sí secular, porque su edición salmantina de 1582 se reimprimió en Alcalá en 1586, reproduciéndose una vez en el dieciocho, pero no en España, sino en Ginebra (1766) y otra a comienzos del XIX (Madrid, 1804).

Estos datos arrojan luz indirecta sobre el enorme eco obtenido por el poeta cordobés y su glosador vallisoletano durante tantas décadas de la centuria renacentista, en la que no se concibió la lectura del uno sin la del otro, la lectura de las trescientas estrofas sin la compañía de los comentarios editoriales, eruditos e interpretativos de Hernán Núñez. Esa fortuna es un dato más que, unido a otros muchos, prueba la perduración de las letras medievales en pleno siglo XVI.
Cabría preguntarse hasta qué punto la metodología y técnicas del Comendador griego en su labor filológica pudo influir y cómo en otros glosadores de textos poéticos desde que se publicó su paradigmática edición, y máxime la que le editó Juan Varela en Granada en 1505, $y$ que es la que han rescatado Weiss y Cortijo Ocaña. Si enorme fue el trabajo de Núñez sobre Mena, copiosísima ha sido la tarea en la que se han empeñado los dos editores contemporáneos, y haría falta, para peritarla cabalmente punto por punto, no una reseña como la presente, sino un texto del género artículoreseña que no me he planteado acometer aquí.

Para concluir ese apunte de noticia y presentación de ese trabajo de Julian Weiss y de Antonio Cortijo Ocaña anotaré las cualidades que en él aprecio: edición admirable por lo ejemplar en estos menesteres. Trabajo editor y estudio monográfico pacientes, meticulosos, muy precisos, y abundantes sin superfluidades. Valiosísimo libro, en suma, y todo un hito en la edición crítica actual. 